\title{
The Effect of Liquidity Risk on Stock Returns: The Case of Amman Stock Exchange during (2004-2013)
}

\author{
Mohamad Ali Bataineh \\ Dima Waleed Hanna Alrabadi \\ Master of Finance and Banking Sciences \\ Associate Prof., of Finance \& Banking Sciences \\ Yarmouk University \\ Hashemit Kingdom of Jordan
}

\begin{abstract}
:
This study examines the effect of individual stock liquidity on its rate of return for the companies listed in Amman Stock Exchange over the period (2004-2013). Our date consists of daily observations of a sample of 30 companies have been selected on a certain filtering process. Fixed effect panel regression analysis is used for estimation purposes. The results of the study show a highly significant effect of liquidity on stock returns. The results also indicate that all the liquidity proxies that have been used in this study including (absolute bid-ask spread, proportional bid-ask spread, volume, dinar volume, turnover, Amihud (2002) illiquidity ratio, depth, dinar depth) show statistically significant effect on individual stock returns for the companies listed in ASE over the study period. Amihud (2002) Illiquidity ratio and turnover rate have the most dominant effect.
\end{abstract}

Keywords: Liquidity risk, individual stock, stock return, fixed effect panel regression, ASE.

\section{Introduction}

We can define liquidity as the degree to which an asset or security can be bought or sold in the market easily, quickly and without affecting its price. High liquidity is characterized by a high level of trading activity. Assets that can be easily bought or sold are known as liquid assets. In other words, it's the ability to convert an asset to cash quickly with little or no loss in value. Liquidity Risk is the risk stemming from the lack of marketability of an investment that cannot be bought or sold quickly enough to prevent or minimize a loss. Liquidity risk is typically reflected in unusually wide bid-ask spreads or large price movements (especially to the downside). The rule of thumb is that the smaller the size of the security or its issuer, the larger the liquidity risk. Several researchers have found that liquidity risk is important in assets pricing. On the aggregate market level, liquidity is found as a systematic risk factor that has been added to models such as CAPM and Fama and French (1993) three-factor model in order to explain the cross section of stock returns (see for example, Fama and French, 1992; Amihud, 2002; Diether et al., 2002).

Moreover, the liquidity of the individual stock is found to significantly affect its rate of return (see for example, Chordia et al., 2005; Kaniel et al., 2008). The effect of liquidity risk is expected to be more dominant in emerging markets that suffer from many problems such as thin trading, asymmetric information, transaction costs and etc. This study investigates the effect of liquidity risk on stock returns. The sample consists of companies listed in Amman Stock Exchange (ASE) over the period (2004 - 2013). In fact, Amman stock Exchange is an emerging market which faces many challenges such as thin trading, small market capitalization, limited number of companies and only some of them (not all) are considered free float (are traded and not held by owners).

* This article was submitted in April 2015, and accepted for publishing in June 2015. 
Consequently, stocks in ASE are more vulnerable to liquidity risk which in turn makes this topic important to study. This study focuses on individual liquidity risk and its effect on stock returns. The remainder of this study is organized as follows: Section 2 reviews the related studies, Section 3 presents our methodology, Section 4 reports the results of analysis and Section 5 concludes.

\section{Literature Review}

Several researchers have examined the effect of liquidity risk on stock returns, we review the followings:

(Chikore et. al., 2014) have recently examined the relationship between stock liquidity and returns using evidence from Zimbabwe Stock Exchange (an emerging market). The analysis is based on the data from February 2009 to December 2012. To measure liquidity; trading volume, turnover rate and relative bid-ask spread are used. Vector Auto Regression Model is applied to examine the relationship between stock liquidity and returns. . The findings indicate that liquidity negatively affects stock returns of Zimbabwe Stock Exchange. Granger causality test shows that the null hypothesis that liquidity does not Granger cause stock returns is rejected at 5\% significance level. At last, the robustness of the findings is tested by considering the impulse response functions and variance decompositions.

(Akram, 2014) examines the relationship between stock returns and liquidity using data from Karachi stock exchange over the period (2005 - 2012). To measure liquidity, bid-Ask spread is used as a proxy variable. Using stage regression, the study concludes that liquidity and stock returns have negative relationship which contradicts many studies of US Market.

(Batten \& Vo, 2014) investigate the relationship between stock returns and liquidity during the global financial crisis in Vietnam. The data set consists of different firms from January 2007 to June 2010. Multivariate Regression model is used for the purposes of the study. The findings reveal that there is a positive relationship between liquidity and stock returns whereas most of the other studies depict the opposite. This is because these studies are conducted for developed markets and this paper used the dataset of an emerging market during the global financial crisis. So this study concluded that if an emerging market is not fully integrated with the global economy, the lack of liquidity is not a significant risk factor.

(NOVAK, 2014) investigates if the stock liquidity explains the premium for stock price momentum in Sweden markets using the pre-crisis data from the Stockholm Stock Exchange covering the period between 1979 and 2005. He uses Fama-MacBeth regressions and finds some evidence on the positive relationship between past and future stock returns, though its significance depends on the treatment of outliers. Also he provides evidence that liquidity is relevant for realized stock returns, and he shows that the inclusion of liquidity proxies does not weaken the explanatory power of momentum.

(Li et. al.,2014 ) investigates whether liquidity risk is priced in Japan. Data is collected from Japanese stock market from 1975 through 2006. Using a modified Amihud illiquidity measure, the relationship between cross-sectional return and liquidity has been examined. The results of this measure show that illiquidity has a positive impact on stock returns in Japan in most of the time excepting the period of 1990-2006. To study whether liquidity risk is priced in the Japanese stock market, liquidity-adjusted CAPM is used. The results show that liquidity risk is also priced in the stock market, which is similar to the findings in the US. The findings 
indicate that liquidity has a strong relationship with stock returns.

(Wei-Lu et. al.,2013 ) investigate the relationship between liquidity and expected return. The paper analyzes the Chinese stock markets from January 2001 to December 2011 (132 months). The study focuses on the stock market liquidity premium theory which depicts that there is a negative relationship between liquidity and expected return. Turnover rate and Amivest liquidity ratio are used to measure stock liquidity. Data is analyzed using multiple regression model. The results contradict the stock market liquidity premium theory when turnover rate is used as a liquidity proxy and supports the theory when Amivest liquidity ratio is used. A Panel Data model is also used to investigate the relationship between liquidity and expected return. The results of this model support the liquidity premium theory for both measures of liquidity.

(Cao \& Petrasek, 2013) investigate the factors that influence the relative performance of stocks during liquidity crises. Proportional quoted bid-ask spread and proportional effective bid-ask spread are used to identify liquidity crises over the period (1993 to 2001). Eventstudy approach is used to examine which factor has relatively greater effect on abnormal stock returns during liquidity crises. Data is analyzed at both the portfolio level and the firm level. The paper concludes that liquidity beta which is measured by the sensitivity of stock returns to market-wide liquidity shocks is able to explain $52 \%$ of the cross-sectional variations of stock returns during liquidity crises whereas market risk which is measured by the market beta, is not such a good indicator of abnormal stock returns during liquidity crises.

(Vovchak, 2013) examines the relative importance of liquidity level over the liquidity risk, two components of liquidity, on the cross section of stock returns. The data set consists of stock returns of NYSE and AMEX from 1964 to 2010. To achieve the purpose of the study five portfolios sorted on liquidity risk and five others sorted on liquidity level are constructed. Then the returns of each portfolio are analyzed through a regression model of different pricing factors. The study concludes that the Amihud illiquidity measure has a better explanatory power than a number of liquidity risk measures. Based on the findings, this paper suggests that investors still need to take individual stock liquidity into account more than the sensitivity to aggregate market liquidity.

(Chen \& Lee, 2013) analyze the effect of market liquidity on default risk and equity returns. The study focuses on the Taiwanese stock market that is characterized by volatility, liquidity and small individual investors which making it different from other developed markets. The accounting and daily stock data cover the period from 1986 to 2008. Default risk is measured through Merton model. This study concludes that size, Book-to-market ratio, and liquidity are strongly related to Default risk but Book-to-market ratio is more crucial factor than the liquidity effect in explaining default risk because of the high liquidity in the Taiwan Market. The results of the cross sectional regression have been revealed that the short-term return reversal exists in the Taiwan Market but this return persists for more than one month which is different from U.S markets. This study also reveals that there is a positive relationship between default risk and equity returns only when the market risk factor is considered in the asset pricing model.

(Bond \& Chang, 2013) investigate the effect of innovations in liquidity on stock-return volatility under a return-decomposition framework. They use regressions analysis over the period from 1982 to 2011 for the firms listed in Institutional Brokers Estimate System (IBES). They 
find that liquidity proxies tend to explain stock returns better during negative market liquidity shocks.

(Morken \& Jerko, 2012) show how liquidity should be measured. They use a data set consists of daily data of OSE (Oslo Stock Exchange) from January 2000 to December 2010. A multi-perspective approach is used to select as well as to compare the measures of liquidity. Then Fama-MacBeth regressions are used to evaluate the performance of the factors used to measure liquidity. The used factors are amortized spread, trading volume, turnover in shares and market risk factor. Their findings indicate that turnover rate can express risk in a better way than the other liquidity proxies. This research also concludes that trade-based measures are more important than order based measures. The Fama-MacBeth regressions show that multifactor model can perform better than capital asset pricing model (CAPM).

(Jang et. al.,2012 ) suggest a new measure to capture liquidity and simplify its multidimensionality taking evidence from Korea. The data covers the period from January 1987 to July 2010. In this study a new two-factor model is introduced which is based on market and liquidity risk factors. This model can explain the stock return more efficiently as it can depict liquidity premium, size and value effects simultaneously which cannot be explained through the most commonly used models: CAPM and Fama-French (1993). The model supports the notion that liquidity has explanatory power in describing stock returns in Korea.

(Fu et. al.,2012 ) investigate why liquidity variations should be considered in determining the impact of liquidity on stock return. Based on the data of NYSE and AMEX from July 1963 to December 2010, the liquidity change is analyzed. The analysis shows that stocks that have experienced a significant increase (decrease) in liquidity are expected to decrease (increase) their liquidity in the next month, and accordingly, they are expected to earn high (low) expected returns in the next month The study concludes that in addition to the liquidity level, liquidity variations should also be considered to explain the stock returns.

(Liang \& Wei, 2012) investigate the effect of liquidity risk on stock return around the world. The study examines 11 developed markets in different countries around the world. They use the estimation of the past liquidity risk betas and GMM estimation. They find that local liquidity, in addition to the local market, value and size factors, demand a systematic premium across stocks in 11 developed markets.

They also discover that global liquidity risk is a significant pricing factor across all developed country market portfolios after controlling for global market, value, and size factors.

(Erten \& Okay, 2012) examine the relationship between illiquidity, liquidity risk and stock returns of Istanbul Stock Exchange over the period of 2005 to 2012. Illiquidity ratio of Amihud (2002) is used to measure liquidity in order to examine the impact of liquidity on stock returns, a Liquidity-Adjusted Capital Asset Pricing Model (unconditional) is used in the study and OLS regressions are applied to 8 illiquidity portfolios. A conditional Liquidity-Adjusted Capital Asset Pricing Model is used to understand the effect of variation of liquidity on stock returns. They find supporting evidence that both illiquidity level and liquidity risk have a significant impact on the cross-section of stock returns in Turkey. Also their findings indicate that while illiquidity is persistent and lowers stock returns, liquidity risk is significantly and positively priced. 
(Akbas et. al., 2011) investigate the volatility of liquidity and expected stock returns in USA market, using sample consisting of NYSE-AMEX common stocks for the period from January 1964 to December 2009. In this article, the researchers use regression analysis in which an aggregate liquidity factor is employed.The results show that there is a significant positive relationship between the volatility of liquidity and expected returns.

(Salehi et. al., 2011) examine the relationship between stock returns and liquidity. The data analyzed in this study is of different companies listed in Tehran Stock Exchange during the period of 2002-2009. Single variable regression is used on quarterly, yearly and monthly basis. The results of the study indicate that there is a negative correlation between stock returns and liquidity which supports most of the studies conducted to investigate the relationship between stock returns and liquidity.

(Hameed \& Viswanathan, 2010) examine the relationship between market declines and liquidity dry-ups as an indicator of capital constraints in the marketplace. The analysis is based on a data set consists of ordinary stocks from NYSE over the period (January 1988 to December 2003). They document inter-industry spillover effects in liquidity, which are likely to arise from capital constraints in the market making sector. Also they find economically significant returns to liquidity suppliers following periods of large drops in market valuations.

(Dalgaard, 2009) investigates the relationship between the stock price and its liquidity in Denmark. The data used in the study includes listed Danish stocks from (January 1987 to November 2008). To measure liquidity, relative bid-ask spread and the turnover rates are used. Fama and Macbeth cross-sectional framework is used to understand the relationship between stock price and liquidity in Denmark for both measures of liquidity. The researcher concludes that there is neither a strong evidence of a return premium for illiquidity nor a return premium for liquidity risk.

(Uddin, 2009) aims to reexamine the negative relationship between stock returns and liquidity using a relative measure which links market wide liquidity and individual liquidity. He studies NYSE and AMEX over the period (January 1966 - December 1995). A Multivariate Regression model is used to investigate the relationship. He uses a new measure of liquidity which is termed as RML (Relative Market Liquidity). This paper concludes that there is a negative but non-linear relationship between the excess stock return and level of RML. It also indicates that there is no positive relationship between variability of RML and the excess stock return which contradicts the first findings. This contradiction has been explained that investors may not necessarily concern highly about the fluctuations of a stock's liquidity, when average market liquidity is lower than its liquidity.

(De \& Ivaschenko, 2009) have introduced new indicators of liquidity for equity, bond and money markets not only for developed but also for emerging markets. The period of data ranges from the (January 1988 to March 1993) from NYSE. Data used in the study consists of monthly data on inflation and interest rates and $\mathrm{P} / \mathrm{E}$ ratios for the broad stock market by country. The study has reached to three major conclusions. first, since the early 1990s, liquidity and systemic liquidity shocks has been increased. Second, liquidity is important in developed economies to determine bond spreads, in emerging economies to determine EMBI (Emerging Markets Bond Index) spreads. Finally, the paper suggests that liquidity should be improved as it is one of the determinants of returns as well as economic growth. 
(Mazouz et. al., 2009) examine the relationship between systematic liquidity risk and stock price reaction to large one-day price changes (or shocks). They base their analysis on 642 constituents of the FTSEALL share index. The analysis covers the period from the 1st of July 1992 to the 29th of June 2007. They use proportional quoted bid-ask spread to generate historical liquidity betas. Then, they sort stocks according to their historical liquidity betas and assign these stocks to decile portfolios ranging from the most liquid to the least liquid. They examine the abnormal returns of the stocks in each of the ten portfolios after large price shocks.

They find that stocks with high return covariate with the overall market liquidity. They show that high liquidity stocks react efficiently to shocks of different signs and magnitudes, whereas low liquidity stocks overreact to negative shocks and under react to positive shocks. Thus, trading on the price patterns following shocks may not be profitable, as it involves taking substantial systematic liquidity risk.

(Yuanhui, 2008) provides a method to measure liquidity risk as well as a complete database for liquidity risk management of China's stock market. The required data was collected during the first six months of the year 2007, from 121 shares of different regions for each industry. The research model is based on VaR (Value at Risk) method. The value of VaR varies from industry to industry as well as market to market. The calculated liquidity risk is $0.2068 \%$ and $0.4035 \%$ for two different regions. And finally, the paper concludes that for better risk management, information sharing system and stock derivatives should be strengthened by formulating improved laws and policy.

(Spiegel \& Wang, 2008) analyze the importance of idiosyncratic risk and liquidity in stock return with empirical evidence. The analysis is based on the CRSP monthly stock return file data from (January 1962 to December 2003). This was supplemented with four of the cost based liquidity measures discussed in Hasbrouck (2005) which are Gibbs, Gamma, Amihud, and Amivest. The paper shows that the idiosyncratic risk and liquidity are negatively correlated which supports past researches. Moreover, this study concludes that idiosyncratic risk has greater explanatory power to determine the stock return than liquidity.

(Xu \& Watada, 2008) investigate liquidity impact on sector returns in stock exchanges in China using a sample consists of Shanghai and Shenzhen Stock Exchanges for the period from February 1 to September 22 in 2007. Two innovations are embodied in the study. First, the liquidity is estimated by a nonparametric regression model. second, the study emphasizes particularly on the liquidity impact on sector returns rather than overall stock returns with the liquidity weighted model, which may be sensible to the investment of fund companies. The results indicate that there is a negative relationship between return and liquidity and the expected returns of sectors are obviously reduced with liquidity impact. Also, the expected return of finance sector witnesses a weaker liquidity impact than the ones of traffic facilities and nonferrous metal sectors.

(Zhang \& Pereira, 2008) investigate the relationship between stock returns and the volatility of liquidity using a sample of monthly returns for NYSE and AMEX stocks for the period $(1966$ - 1995). They find that higher volatility in liquidity offers more opportunity for the investor to time his/her trades and is therefore associated with a lower required liquidity premium.

(Watanabe \& Watanabe, 2007) examine whether the aggregate liquidity fluctuations has impact on stock returns as well as whether the pricing of liquidity risk varies over time. Using Markov regime-switching model, this paper finds that liquidity betas vary significantly over 
time and across two different states having high liquidity betas and low liquidity betas. The high liquidity-beta state has heavy trade, high volatility and a wide cross-sectional fluctuation in liquidity betas. The transition from the low to the high liquidity-beta state is predicted by a rise in trading volume. Again, using a conditional liquidity factor, this paper documents that the cross-sectional pricing of liquidity risk strengthens in the high liquidity-beta state.

(Bekaert et. al., 2007) have examined the relationship between liquidity and expected returns. The data used is of 19 emerging markets covering the period from January 1987 to December 2003. To measure liquidity, a transformation of the proportion of zero daily firm returns is used as this measure significantly predicts returns but the other measures of the liquidity do not. According to this study, unexpected liquidity shocks are positively correlated with contemporaneous return shocks and negatively correlated with shocks of the dividend yield. The findings from asset pricing model indicate that local market liquidity can significantly affect expected returns in emerging markets. This research also concludes that countries with high political risk and poor law and order conditions can be more affected by liquidity risk.

(Chacko, 2005) examines whether liquidity risk is priced taking evidence from US corporate bond transactions and holdings. A liquidity measure is introduced in the study which assesses the accessibility of a bond, rather than its trading volume. Using regression analysis it has been found that the liquidity risk factor is an important determinant of bond returns and that it is priced. The study also concludes that liquidity risk factor is an important determinant for returns from a number of asset classes and hence it can be regarded as universal risk factor.

(Giouvris, 2003) investigates the effect of systematic liquidity on expected returns in London Stock Exchange using daily data from October 1996 to May 2001, incorporating four different trading/price reporting regimes. He finds that liquidity proxied by absolute and proportional bid-ask spread has decreased over the years despite attempts of the London Stock Exchange to make the UK market a more competitive market. Absolute and proportional spread exhibit a systematic time varying risk component even after controlling for a number of variables known to affect return. Thus, spread and systematic liquidity appears to have an important role on stock pricing before the introduction of SETS (order-driven stock exchange electronic trading service) but decreases for the rest of the periods/trading regimes examined.

(Pastor \& Stambaugh, 2001) investigate the effect of liquidity risk on expected stock returns, the study examine NYSE, AMEX, and NASDAQ for the period from 1965 to 2000. Bid-ask spread measure, the turnover measure, and the Amihud (2002) illiquidity ratio are used to measure liquidity and Merton's contingent claims approach is used to measure default risk. The Regression results and Vector Autoregressive (VAR) tests show that the three alternative liquidity measures are not highly correlated with each other but default measure is highly correlated with liquidity which is consistent for the three used alternative liquidity measures. The study also shows that none of the liquidity proxies Granger-causes future stock market returns but there is a causal relationship between the default risk and stock market returns.

(Abdallat, 1995) investigates the relationship between systematic risk, nonsystematic risk, company size and liquidity with the stock return. The analysis based on data of Amman Stock Exchange over the period (January 1992 - April 1995). The results indicate that the nonsystematic risk is the major determinant of required return. In addition variables like systematic risk, liquidity and company size are insignificant in explaining the variation in returns of the securities under study. 
(Amihud \& Mendelson, 1986) study the relationship between bid ask spread as a measure of liquidity and stock returns. The analysis is based on the data of New York Stock Exchange over the period of 1961-80. Seven stock portfolios are constructed according to average bidask spread. Applying Capital Asset Pricing Model, it has been found that there is a positive relationship between stock returns and beta risk. The analysis of different sub-periods indicates that the spread variable has a positive and significant effect on stock returns. Finally, this paper concludes that low-liquidity investments are expected to produce higher returns for their holders and longer holding period can reduce illiquidity.

\section{What distinguishes this study from the previous ones?}

ASE is an emerging market that is characterized by high levels of volatility, thin trading, illiquidity and many other problems such as information asymmetry and agency costs. This in fact gives a special importance of liquidity risk to be examined in this stock exchange. To the best of researcher's knowledge, this is the first study in Jordan that examines the effect of liquidity risk measured by all the proxies used on the cross section of stock returns over relatively a long period of time.

\section{Methodology}

\section{Population and sample}

The population of the study consists of all the companies listed in ASE (Amman Stock Exchange) over the period (2004-2013). The numbers of these companies are 262. A filtering process is done to sample the mostly traded stock. The company is included in the analysis if it meets the following conditions:-

1- It should be traded along the study period.

2- Companies which had any mergers or structural changes are excluded.

3- In order for the company to be included, it should be traded at least 10 days on each month along the period of the study.

The filtering process results in 30 companies with daily observations over the period (2004-2013). Thin trading is a serious problem in ASE, it is the reason behind starting with a population of 262 companies and ending with a sample of 30 ones.

\section{Variables of the study}

\section{Dependent variable}

Daily stock return is the dependent variable. It is calculated as follows:

$$
\mathbf{R i}, \mathbf{t}=\ln (\mathbf{P i}, \mathbf{t} \backslash \mathbf{P i}, \mathbf{t}-1)
$$

Where $\mathrm{R}_{\mathrm{i}, \mathrm{t}}$ is the return of stock $\mathrm{i}$ on day $\mathrm{t}, \mathrm{P}_{\mathrm{i}, \mathrm{t}}$ is the closing price of stock $\mathrm{i}$ on day $\mathrm{t}$ and $\mathrm{P}_{\mathrm{i}, \mathrm{t}-\mathrm{1}}$ is the closing price of stock $i$ on the day before day $t$.

\section{Independent variables}

Stock liquidity is the main independent variable. Liquidity is measured using several proxies, absolute bid-ask spread, proportional bid-ask spread, depth, dinar depth, volume, dinar volume, Amihud (2002) illiquidity ratio and turnover rate.

The absolute bid-ask spread is calculated as: 


\section{SPR = Pai,t - Pbi,t (2)}

Where SPR is the absolute bid-ask spread, $\mathrm{P}_{\mathrm{i}, \mathrm{t}}^{\mathrm{a}}$ is the ask price for stock $\mathrm{i}$ at time $\mathrm{t}$, and $\mathrm{P}_{\mathrm{i}, \mathrm{t}}^{\mathrm{b}}$ is the bid price for stock $i$ at time $t$.

The proportional bid-ask spread is calculated as:

$$
\text { PSPR }=(\text { Pai,t }- \text { Pbi,t }) \backslash .5(\text { Pai,t }+ \text { Pbi,t })(3)
$$

Where PSPR is the proportional bid-ask spread, $\mathrm{P}_{\mathrm{i}, \mathrm{t}}^{\mathrm{a}}$ is the ask price for stock $\mathrm{i}$ at time $\mathrm{t}$, and $\mathrm{P}_{\mathrm{i}, \mathrm{t}}^{\mathrm{b}}$ is the bid price for stock $\mathrm{i}$ at time $\mathrm{t}$.

'The quantity depth is calculated as:

$$
\text { DEP }=(\text { Qai,t }+ \text { Qbi,t }) \backslash 2
$$

Where DEP is the volume depth, $\mathrm{Q}_{\mathrm{i}, \mathrm{t}}^{\mathrm{a}}$ is the quantity asked for stock $\mathrm{i}$ at time $\mathrm{t}$ and $\mathrm{Q}_{\mathrm{i}, \mathrm{t}}^{\mathrm{b}}$ is the quantity bided for stock $\mathrm{i}$ at time $\mathrm{t}$.

The dinar depth is calculated as:

$$
\text { DDEP }=(\text { Qai,t * Pai,t + Qbi,t * Pbi,t }) \backslash 2 \text { (5) }
$$

Where $\mathrm{Q}_{\mathrm{i}, \mathrm{t}}^{\mathrm{a}}$ is the quantity asked for stock $\mathrm{i}$ at time $\mathrm{t}, \mathrm{Q}_{\mathrm{i}, \mathrm{t}}^{\mathrm{b}}$ is the quantity bided for stock $\mathrm{i}$ at time $t, \mathrm{P}_{\mathrm{i}, \mathrm{t}}^{\mathrm{a}}$ is the ask price of stock $\mathrm{i}$ at time $\mathrm{t}$ and $\mathrm{P}_{\mathrm{i}, \mathrm{t}}^{\mathrm{b}}$ is the bid price of stock $\mathrm{i}$ at time $\mathrm{t}$.

The Volume is calculated as:

$$
\mathrm{VOL}=\Sigma q \times(6)
$$

Where $\mathrm{q}_{\mathrm{x}}$, is the number of stocks traded for stock $\mathrm{x}$.

The dinar volume is calculated as:

$$
\text { DVOL }=\Sigma P x * q x(7)
$$

Where $\mathrm{P}_{\mathrm{x}}$ is the price of stock $\mathrm{x}$ and $\mathrm{q}_{\mathrm{x}}$ is the number of stocks traded for stock $\mathrm{x}$.

The Amihud (2002) illiquidity ratio is calculated as

$$
\text { AMIHUD }=\mid \text { Ri,t } \mid \backslash \text { DVOLi,t }(8)
$$

Where AMIHUD is the Amihud illiquidity ratio, $\mathrm{R}_{\mathrm{i}, \mathrm{t}}$ is the rate of return of stock $\mathrm{i}$ at time $\mathrm{t}$ and $\mathrm{DVOL}_{\mathrm{i}, \mathrm{t}}$ is the cash volume traded for stock $\mathrm{i}$ at time $\mathrm{t}$.

And the turnover rate is calculated as:

\section{TURNOVER $=\Sigma q x \backslash$ NOi,t (9)}

Where TURNOVER is the turnover rate, $\mathrm{q}_{\mathrm{x}}$ is the number of stocks traded for stock $\mathrm{x}$ and $\mathrm{NO}_{i, t}$ is the number of share outstanding for stock $\mathrm{i}$ at time $\mathrm{t}$.

The independent variables also include some control variables which are the size of the firm and the risk of the stock. The size is calculated as the natural logarithm of the total assets, the risk is calculated as the standard deviation of the daily returns.

\section{The model}

$$
\text { Rit }=\alpha i+\beta 1 \text { LIQit }+\beta 2 i \text { sizeit }+\beta 3 i \text { riskit+eit }
$$

We estimate 8 different models using a different LIQ measure each time. The lagged re- 
turns and liquidity up to three days are also added to the model as control variables.

\section{Estimation Technique}

Panel regression analysis is used to estimate the models. We find that both Logarithm Multiplier test and Hausman test are significant so that the fixed effect model is used.

\section{Hypotheses of the study}

\section{Main Hypothesis}

There is a statistically significant effect of stock's liquidity on its return.

\section{Sub Hypotheses}

$\mathrm{H}_{1}$ : There is a statistically significant effect of absolute bid-ask spread on stock returns.

$\mathrm{H}_{2}$ : There is a statistically significant effect of proportional bid-ask spread on stock return.

$\mathrm{H}_{3}$ : There is a statistically significant effect of depth on stock return.

$\mathrm{H}_{4}$ : There is a statistically significant effect of dinar depth on stock return.

$\mathrm{H}_{5}$ : There is a statistically significant effect of volume on stock return.

$\mathrm{H}_{6}$ : There is a statistically significant effect of dinar volume on stock return.

$\mathrm{H}_{7}$ : There is a statistically significant effect of Amihud illiquidity ratio on stock return.

$\mathrm{H}_{8}$ : There is a statistically significant effect of turnover rate on stock return.

\section{Results of Analysis}

\section{Descriptive statistics}

Table 5-1 reports the descriptive statistics of the study variables. The mean return of the sample stocks over the study is 0.0002 with a maximum value 4.8138 and a minimum value of -2.3120 .

The average SPR is .0588 with a maximum value 40.3800 and a minimum value -76.8600 . The PSPR mean is 0.0230 with a maximum value 2.00 and a minimum value -2.00 . The mean of DEP is 7577.598 and the maximum value of it 1499510.00 and minimum value 1.500 . The DDEP mean is 21569.650 with maximum value 40658940.00 and minimum value 4.650.

The average of TURNOVER is 0.0043 with a maximum value 0.9587 and minimum value 0.000 . The AMIHUD mean is 0.000 with a maximum value 0.0784 and minimum value 0.000 .

The VOL mean is 88145.290 with a maximum value 43879876.00 and minimum value 1.00. The average of DVOL is 492150.100 with a maximum value 319000000.00 and minimum value 0.510 .

This table reports the descriptive statistics of the study variables. RETURN denotes daily stock return. SPR denotes absolute bid-ask spread. PSPR denotes proportional bid-ask spread. DEP denotes depth. DDEP denotes dinar depth. TURNOVER denotes turnover rate. VOL denotes quantity volume. DVOL denotes dinar volume. AMIHUD denotes Amihud illiquidity ratio. SIZE denotes the size of the firm measured by the natural logarithm of total assets. RISK denotes risk measured by the standard deviation of daily stock returns. 
Table 1: Descriptive Statistics

\begin{tabular}{|c|c|c|c|c|c|c|c|c|c|c|c|}
\hline & $\begin{array}{c}\text { RE- } \\
\text { TURN }\end{array}$ & SPR & PSPR & DEP & DDEP & $\begin{array}{l}\text { TURN- } \\
\text { OVER } \\
\end{array}$ & VOL & DVOL & $\begin{array}{l}\text { AMI- } \\
\text { HUD }\end{array}$ & SIZE & RISK \\
\hline $\begin{array}{c}\text { Me } \\
0.00\end{array}$ & $\begin{array}{l}\text { ean } \\
002 \\
\end{array}$ & 0.0588 & 0.0230 & 7577.5980 & 21569.6500 & 0.0043 & 88145.290 & 492150.100 & 0.0000 & 17.3379 & 0.0220 \\
\hline $\begin{array}{l}\text { Me- } \\
\text { dian }\end{array}$ & 0.0000 & 0.0200 & 0.0096 & 1150.0000 & 3930.8250 & 0.0005 & 16742.000 & 51464.9600 & 0.0000 & 17.3709 & 0.0184 \\
\hline $\begin{array}{c}\text { Maxi- } \\
\text { mum }\end{array}$ & 4.8138 & 40.380 & 2.0000 & 1499510.000 & 40658940.000 & 0.9587 & 43879876.000 & 319000000.000 & 0.0784 & 20.0959 & 1.1042 \\
\hline $\begin{array}{l}\text { Mini- } \\
\text { mum }\end{array}$ & -2.3120 & -76.860 & -2.0000 & 1.5000 & 4.6500 & 0.0000 & 1.000 & 0.5100 & 0.0000 & 14.9942 & 0.0000 \\
\hline $\begin{array}{l}\text { Std. } \\
\text {.Dev }\end{array}$ & 0.0392 & 1.2239 & 0.3134 & 35496.7300 & 268250.300 & 0.0176 & 324828.000 & 2410281.000 & 0.0005 & 1.1986 & 0.0316 \\
\hline
\end{tabular}

\section{Estimation Results}

Table 2 presents the effect of absolute bid-ask spread on stock returns. There is a statistically significant positive effect of absolute bid-ask spread on stock returns with a coefficient value of 0.0035 . Accordingly we accept $\mathrm{H}_{1}$ (There is a statistically significant effect of absolute bid-ask spread on stock's return).

The Adjusted R-squared for this for this Model is $33.74 \%$ which means that the model estimated in Table 2 explains $33.74 \%$ of the changes in stock returns.

Table 2: The effect of absolute bid-ask spread on stock return

\begin{tabular}{ccccc}
\hline Variable & Coefficient & Std. Error & t- Statistic & .Prob \\
\hline C & 0.0217 & 0.0049 & 4.4591 & 0.0000 \\
\hline SPR & 0.0035 & 0.0001 & -35.2718 & 0.0000 \\
\hline SIZE & 0.0012 & 0.0003 & -4.2364 & 0.0000 \\
\hline RISK & 0.0475 & 0.0042 & -11.4404 & 0.0000 \\
\hline RETURN(-1) & 0.0560 & 0.0047 & 11.8516 & 0.0000 \\
\hline RETURN(-2) & -0.0045 & 0.0047 & -0.9614 & 0.3364 \\
\hline RETURN(-3) & 0.0054 & 0.0030 & 1.8260 & 0.0679 \\
\hline SPR(-1) & -0.0001 & 0.0001 & -1.2872 & 0.1980 \\
\hline SPR(-2) & 0.0003 & 0.0001 & 2.3974 & 0.0165 \\
\hline SPR(-3) & 0.0001 & 0.0001 & 0.9969 & 0.3188 \\
\hline R-squared & & $\mathbf{0 . 3 3 8 1}$ & \\
\hline $\begin{array}{c}\text { Adjusted } \\
\text { R-squared- } \\
\text { squared }\end{array}$ & & $\mathbf{0 . 3 3 7 4}$ & \\
\hline
\end{tabular}

These results are consistent with (Amihud and Mendelson, 1986) who finds evidence that the absolute bid-ask spread variable have a positive and significant effect on stock returns for 
US firms. However, the results are contrary to (Akram, 2014) in Pakistan firms and ( Pastor \& Stambaugh, 2001) in US firms who find evidence that the absolute bid-ask spread variable has a negative significant effect on stock returns.

This table reports the estimation results of the absolute bid-ask spread model. SPR denotes the absolute bid-ask spread. SIZE represents the size of the firm measured by the natural logarithm of total assets. RISK denotes the risk of the stock measured by the standard deviation of daily stock returns. RETURN(-1) represents one-day lag of its return. RETURN(-2) represents two-day lag of its return. RETURN(-3) denotes three-day lag of its return. SPR(-1) denotes oneday lag of absolute bid-ask spread. SPR(-2) denotes two-day lag of absolute bid-ask spread. SPR(-3) denote three-day lag of absolute bid-ask spread.

Table 3 presents the effect of proportional bid-ask spread on stock returns. There is a statistically significant positive effect of Proportional bid-ask spread on stock returns with a coefficient value 0.0222 . Accordingly we accept $\mathrm{H}_{2}$ (There is a statistically significant effect of Proportional bid-ask spread on stock's return).

The Adjusted R-squared for this for this Model is $38.05 \%$ which means that the model estimated in Table 3 explains $38.05 \%$ of the changes in stock returns.

These results are consistent with (Amihud and Mendelson, 1986) and (Chordia et. al., 2005) who finds evidence that the proportional bid-ask spread variable has a positive and significant effect on stock returns for US firms.

Table 3: The effect of proportional bid-ask spread on stock return

\begin{tabular}{|c|c|c|c|c|}
\hline Variable & Coefficient & Std. Error & t- Statistic & .Prob \\
\hline C & 0.0141 & 0.0048 & 2.9517 & 0.0032 \\
\hline PSPR & 0.0222 & 0.0004 & -56.9733 & 0.0000 \\
\hline SIZE & -0.0007 & 0.0003 & -2.6629 & 0.0077 \\
\hline RISK & 0.0462 & 0.0041 & -11.3796 & 0.0000 \\
\hline RETURN(-1) & 0.0326 & 0.0047 & 6.8854 & 0.0000 \\
\hline RETURN(-2) & -0.0120 & 0.0047 & -2.5371 & 0.0112 \\
\hline RETURN(-3) & 0.0039 & 0.0029 & 1.3225 & 0.1860 \\
\hline PSPR(-1) & -0.0024 & 0.0004 & -5.8069 & 0.0000 \\
\hline PSPR(-2) & 0.0015 & 0.0004 & 3.7488 & 0.0002 \\
\hline PSPR(-3) & 0.0008 & 0.0004 & 2.1771 & 0.0295 \\
\hline R-squared & \multicolumn{4}{|c|}{0.3811} \\
\hline $\begin{array}{c}\text { Adjusted } \\
\text { R-squared } \\
\end{array}$ & \multicolumn{4}{|c|}{0.3805} \\
\hline
\end{tabular}

This table reports the estimation results of the proportional bid-ask spread model. PSPR denotes the proportional bid-ask spread. SIZE represents the size of the firm measured by the natural logarithm of total assets. RISK denotes the risk of the stock measured by the standard deviation of daily stock returns. RETURN (-1) represents one-day lag of its return. RETURN 
(-2) represents two-day lag of its return. RETURN (-3) denotes three-day lag of its return. PSPR (-1) denotes one-day lag of proportional bid-ask spread. PSPR (-2) denote two-day lag of proportional bid-ask spread. PSPR (-3) denotes three-day lag of proportional bid-ask spread.

Table 4 presents the effect of depth on stock returns. There is a statistically significant negative effect of depth on stock returns with a coefficient value -0.0001 . Accordingly we accept $\mathrm{H}_{3}$ (There is a statistically significant effect of depth on stock's return).

The Adjusted R-squared for this for this Model is $31.53 \%$ which means that the model estimated in Table 4 explains $31.53 \%$ of the changes in stock returns.

These results are consistent with (Chordia et. al., 2005) who find evidence that the depth variable has a negative and significant effect on stock returns for US firms.

Table 4: The effect of depth on stock return

\begin{tabular}{c|cccc}
\hline Variable & Coefficient & Std. Error & t- Statistic & .Prob \\
\hline C & 0.0218 & 0.0049 & 4.4111 & 0.0000 \\
\hline DEP & -0.0001 & 0.0000 & 12.7284 & 0.0000 \\
\hline SIZE & -0.0012 & 0.0003 & -4.3015 & 0.0000 \\
\hline RISK & 0.0511 & 0.0042 & -12.1249 & 0.0000 \\
\hline RETURN(-1) & 0.0700 & 0.0047 & 14.8980 & 0.0000 \\
\hline RETURN(-2) & 0.0003 & 0.0047 & 0.0642 & 0.9488 \\
\hline RETURN(-3) & 0.0066 & 0.0030 & 2.2157 & 0.0267 \\
\hline DEP(-1) & 0.0000 & 0.0000 & 4.7511 & 0.0000 \\
\hline DEP(-2) & 0.0000 & 0.0000 & -2.1084 & 0.0350 \\
\hline DEP(-3) & 0.0000 & 0.0000 & -2.5232 & 0.0116 \\
\hline R-squared & & $\mathbf{0 . 3 1 6 0}$ & \\
\hline $\begin{array}{c}\text { Adjusted } \\
\text { R-squared- } \\
\text { squared }\end{array}$ & & $\mathbf{0 . 3 1 5 3}$ & \\
\hline
\end{tabular}

This table reports the estimation results of the depth model. DEP denotes the depth. SIZE represents the size of the firm measured by the natural logarithm of total assets. RISK denotes the risk of the stock measured by the standard deviation of daily stock returns. RETURN(-1) represents one-day lag of its return. RETURN(-2) represents two-day lag of its return. RETURN(-3) denotes three-day lag of its return. DEP(-1) denote one-day lag of depth. DEP(-2) denotes two-day lag of depth. DEP(-3) denote three-day lag of depth.

Table 5 presents the effect of dinar depth on stock returns. There is a statistically significant negative effect of dinar depth on stock returns with a coefficient value -0.0002 . Accordingly we accept $\mathrm{H}_{4}$ (There is a statistically significant effect of dinar depth on stock's return).

The Adjusted R-squared for this for this Model is $31.05 \%$ which means that the model estimated in Table 5 explains $31.05 \%$ of the changes in stock returns. 
Table 5: The effect of dinar depth on stock return

\begin{tabular}{ccccc}
\hline Variable & Coefficient & Std. Error & t- Statistic & .Prob \\
\hline C & 0.0179 & 0.0049 & 3.6187 & 0.0003 \\
\hline DDEP & -0.0002 & 0.0000 & 8.0278 & 0.0000 \\
\hline SIZE & -0.0010 & 0.0003 & -3.4472 & 0.0006 \\
\hline RISK & 0.0501 & 0.0042 & -11.9063 & 0.0000 \\
\hline RETURN(-1) & 0.0693 & 0.0047 & 14.6767 & 0.0000 \\
\hline RETURN(-2) & -0.0005 & 0.0047 & -0.1077 & 0.9142 \\
\hline RETURN(-3) & 0.0062 & 0.0030 & 2.0505 & 0.0403 \\
\hline DDEP(-1) & 0.0000 & 0.0000 & 1.9414 & 0.0522 \\
\hline DDEP(-2) & 0.0000 & 0.0000 & -2.4550 & 0.0141 \\
\hline DDEP(-3) & 0.0000 & 0.0000 & 1.7416 & 0.0816 \\
\hline R-squared & & $\mathbf{0 . 3 1 1 2}$ & \\
\hline Adjusted & & $\mathbf{0 . 3 1 0 5}$ & \\
\hline R-squared & & & \\
\hline
\end{tabular}

This table reports the estimation results of the dinar depth model. DDEP denotes the dinar depth. SIZE represents the size of the firm measured by the natural logarithm of total assets. RISK denotes the risk of the stock measured by the standard deviation of daily stock returns. RETURN(-1) represents one-day lag of its return. RETURN(-2) represents two-day lag of its return. RETURN(-3) denotes three-day lag of its return. DDEP(-1) denote one-day lag of dinar depth. DDEP(-2) denote two-day lag of dinar depth. DDEP(-3) denote three-day lag of dinar depth.

Table 6 presents the effect of volume on stock returns. There is a statistically significant negative effect of volume on stock returns with a coefficient value -0.0002 . Accordingly we accept $\mathrm{H}_{5}$ (There is a statistically significant effect of volume on stock's return). The Adjusted $\mathrm{R}$-squared for this for this Model is $31.24 \%$ which means that the model estimated in Table 6 explains $31.24 \%$ of the changes in stock returns.

These results are consistent with (Chikore et. al., 2014) who find evidence that the volume variable have a negative effect on stocks return in Zimbabwe firms.

This table reports the estimation results of the quantity volume model. VOL denotes the volume. SIZE represents the size of the firm measured by the natural logarithm of total assets. RISK denotes the risk of the stock measured by the standard deviation of daily stock returns. RETURN(-1) represents one-day lag of its return. RETURN(-2) represents two-day lag of its return. RETURN(-3) denotes three-day lag of its return. VOL(-1) denote one-day lag of volume. VOL(-2) denote two-day lag of volume. VOL(-3) denote three-day lag of volume.

Table 7 presents the effect of dinar volume on stock returns. There is a statistically significant negative effect of dinar volume on stock returns with a coefficient value -0.0004. Accordingly we accept $\mathrm{H}_{6}$ (There is a statistically significant effect of dinar volume on stock's return).

The Adjusted R-squared for this for this Model is $31.08 \%$ which means that the model estimated in Table 7 explains $31.08 \%$ of the changes in stock returns. 
Table 6: The effect of volume on stock return

\begin{tabular}{ccccc}
\hline Variable & Coefficient & Std. Error & t- Statistic & .Prob \\
\hline C & 0.0190 & 0.0049 & 3.8367 & 0.0001 \\
\hline VOL & -0.0002 & 0.0000 & 12.9798 & 0.0000 \\
\hline SIZE & -0.0011 & 0.0003 & -3.7071 & 0.0002 \\
\hline RISK & 0.0504 & 0.0042 & -11.9523 & 0.0000 \\
\hline RETURN(-1) & 0.0706 & 0.0047 & 15.0230 & 0.0000 \\
\hline RETURN(-2) & -0.0005 & 0.0047 & -0.1019 & 0.9188 \\
\hline RETURN(-3) & 0.0062 & 0.0030 & 2.0572 & 0.0397 \\
\hline VOL(-1) & 0.0000 & 0.0000 & 0.1021 & 0.9187 \\
\hline VOL(-2) & 0.0000 & 0.0000 & -1.7437 & 0.0812 \\
\hline VOL(-3) & 0.0000 & 0.0000 & -1.8887 & 0.0589 \\
\hline R-squared & & $\mathbf{0 . 3 1 3 1}$ & \\
\hline Adjusted R-squared & & $\mathbf{0 . 3 1 2 4}$ & \\
\hline
\end{tabular}

Table 7: The effect of dinar volume on stock return

\begin{tabular}{ccccc}
\hline Variable & Coefficient & Std. Error & t- Statistic & .Prob \\
\hline C & 0.0177 & 0.0050 & 3.5633 & 0.0004 \\
\hline DVOL & -0.0004 & 0.0000 & 9.7843 & 0.0000 \\
\hline SIZE & -0.0010 & 0.0003 & -3.3843 & 0.0007 \\
\hline RISK & 0.0499 & 0.0042 & -11.8086 & 0.0000 \\
\hline RETURN(-1) & 0.0723 & 0.0047 & 15.3726 & 0.0000 \\
\hline RETURN(-2) & 0.0008 & 0.0047 & 0.1696 & 0.8653 \\
\hline RETURN(-3) & 0.0068 & 0.0030 & 2.2563 & 0.0241 \\
\hline DVOL(-1) & 0.0000 & 0.0000 & -1.3456 & 0.1784 \\
\hline DVOL(-2) & 0.0000 & 0.0000 & -3.6320 & 0.0003 \\
\hline DVOL(-3) & 0.0000 & 0.0000 & -2.2256 & 0.0260 \\
\hline R-squared & & $\mathbf{0 . 3 1 1 5}$ & \\
\hline Adjusted R-squared & & $\mathbf{0 . 3 1 0 8}$ & \\
\hline
\end{tabular}

This table reports the estimation results of the quantity dinar volume model. DVOL denotes the dinar volume. SIZE represents the size of the firm measured by the natural logarithm of total assets. RISK denotes the risk of the stock measured by the standard deviation of daily stock returns. RETURN(-1) represents one-day lag of its return. RETURN(-2) represents two-day lag of its return. RETURN(-3) denotes three-day lag of its return. DVOL(-1) denote one-day lag of dinar volume. DVOL(-2) denote two-day lag of dinar volume. DVOL(-3) denote three-day lag of dinar volume.

Table 8 presents the effect of turnover on stock returns. There is a statistically significant positive effect of turnover on stock returns with a coefficient value 0.1801 . Accordingly we accept $\mathrm{H}_{7}$ (There is a statistically significant effect of turnover on stock's return). 
The Adjusted R-squared for this for this Model is $31.65 \%$ which means that the model estimated in Table 8 explains $31.65 \%$ of the changes in stock returns.

These results agree with (Bond \& Chang, 2013) who find evidence that the turnover rate has a positive significant effect on stock returns in U.S firms. Also, (Chordia et. al.,2005) find evidence that the turnover rate has a positive significant effect on stock returns in U.S firms. But, the results do not conform with (Wei-Lu et. al., 2013) in Chinese firms and (Pastor \& Stambaugh, 2001) in U.S firms who find evidence that the turnover rate has a negative significant effect on stock returns.

Table 8: The effect of turnover on stock return

\begin{tabular}{ccccc}
\hline Variable & Coefficient & Std. Error & t- Statistic & .Prob \\
\hline C & 0.0148 & 0.0050 & 2.9775 & 0.0029 \\
\hline TURNOVER & 0.1801 & 0.0097 & 18.5754 & 0.0000 \\
\hline SIZE & -0.0008 & 0.0003 & -2.8332 & 0.0046 \\
\hline RISK & 0.0503 & 0.0042 & -11.9487 & 0.0000 \\
\hline RETURN(-1) & 0.0681 & 0.0047 & 14.4930 & 0.0000 \\
\hline RETURN(-2) & -0.0003 & 0.0047 & -0.0626 & 0.9501 \\
\hline RETURN(-3) & 0.0064 & 0.0030 & 2.1403 & 0.0323 \\
\hline TURNOVER(-1) & -0.0216 & 0.0101 & -2.1287 & 0.0333 \\
\hline TURNOVER(-2) & -0.0553 & 0.0104 & -5.3115 & 0.0000 \\
\hline TURNOVER(-3) & -0.0455 & 0.0101 & -4.4814 & 0.0000 \\
\hline R-squared & & $\mathbf{0 . 3 1 7 1}$ & \\
\hline $\begin{array}{c}\text { Adjusted } \\
\text { R-squared }\end{array}$ & & $\mathbf{0 . 3 1 6 5}$ & \\
\hline
\end{tabular}

This table reports the estimation results of the turnover rate model. TURNOVER denotes the turnover rate. SIZE represents the size of the firm measured by the natural logarithm of total assets. RISK denotes the risk of the stock measured by the standard deviation of daily stock returns. RETURN(-1) represents one-day lag of its return. RETURN(-2) represents two-day lag of its return. RETURN(-3) denotes three-day lag of its return. TURNOVER(-1) denote one-day lag of turnover rate. TURNOVER(-2) denote two-day lag of turnover rate. TURNOVER(-3) denote three-day lag of turnover rate.

Table 9 presents the effect of Amihud illiquidity ratio on stock returns. There is a statistically significant positive effect of Amihud illiquidity ratio on stock returns with a coefficient value 2.5883. Accordingly we accept $\mathrm{H}_{8}$ (There is a statistically significant effect of Amihud illiquidity ratio on stock's return).

The Adjusted R-squared for this for this Model is 30.94\% which means that the model estimated in Table 9 explains $30.94 \%$ of the changes in stock returns.

These result are appropriate with (Li et. al., 2014) who finds evidence that the Amihud illiquidity ratio has a positive significant effect on stock returns in Japanese companies. Also, the results are consistent with (Erten \& Okay, 2012) who find evidence that the Amihud illiquidity ratio has a positive significant effect on stock returns in Turkish companies. Likewise, the results 
conflict with (Spiegel \& Wang, 2008) and (Pastor \& Stambaugh, 2001) who finds evidence that the Amihud illiquidity ratio has a negative significant effect on stock returns in US companies.

Table 9: The effect of Amihud illiquidity ratio on stock return

\begin{tabular}{ccccc}
\hline Variable & Coefficient & Std. Error & t- Statistic & .Prob \\
\hline C & 0.0190 & 0.0050 & 3.8302 & 0.0001 \\
\hline AMIHUD & 2.5883 & 0.4593 & 5.6357 & 0.0000 \\
\hline SIZE & -0.0010 & 0.0003 & -3.6411 & 0.0003 \\
\hline RISK & 0.0491 & 0.0042 & -11.6220 & 0.0000 \\
\hline RETURN(-1) & 0.0748 & 0.0047 & 15.9242 & 0.0000 \\
\hline RETURN(-2) & 0.0014 & 0.0047 & 0.3025 & 0.7623 \\
\hline RETURN(-3) & 0.0067 & 0.0030 & 2.2199 & 0.0264 \\
\hline AMIHUD(-1) & -0.4996 & 0.2781 & -1.7965 & 0.0724 \\
\hline AMIHUD(-2) & -0.2420 & 0.2757 & -0.8778 & 0.3800 \\
\hline AMIHUD(-3) & 0.1061 & 0.2770 & 0.3829 & 0.7018 \\
\hline R-squared & & & $\mathbf{0 . 3 1 0 0}$ & \\
\hline $\begin{array}{c}\text { Adjusted } \\
\text { R-squared }\end{array}$ & & $\mathbf{0 . 3 0 9 4}$ & \\
\hline
\end{tabular}

This table reports the estimation results of the Amihud illiquidity ratio model. AMIHUD denotes the Amihud illiquidity ratio. SIZE represents the size of the firm measured by the natural logarithm of total assets. RISK denotes the risk of the stock measured by the standard deviation of daily stock returns. RETURN(-1) represents one-day lag of its return. RETURN(-2) represents two-day lag of its return. RETURN(-3) denotes three-day lag of its return. AMI$\operatorname{HUD}(-1)$ denote one-day lag of Ami decile hud illiquidity ratio. AMIHUD(-2) denote two-day lag of amihud illiquidity ratio. AMIHUD(-3) denote three-day lag of Amihud illiquidity ratio.

The results in all tables show a statistical significant positive effect of risk on stock returns and statistical significant negative effect of size on stock return.

\section{Conclusion}

This study has investigated the effect of individual stock's liquidity on its return. Our data consists of daily observations of 30 corporation listed in ASE over the period (2004-2013). The findings indicate that absolute bid-ask spread, proportional bid-ask spread, turnover rate and Amihud (2002) illiquidity rate have significant positive effect on stock returns. On the other hand, depth, dinar depth, volume, and dinar volume show significant negative effect on stock returns. These findings point out that liquidity risk in all its dimensions and regardless of the proxy used are found to significantly affect the stock return at the individual level for the companies listed in ASE. In fact, Amihud illiquidity ratio and turnover rate have the largest effect on stock return comparing with the other proxies examined. This indicates that these two proxies capture liquidity risk much better than the order measures (spread and depth proxies). 


\section{References}

- Abdallat, M. (1995) . The Impact of Investment, Liquidity and Volume on Stock Returns: An Analytical Study of the Shares Listed on the Amman Financial Market Companies. Master Thesis, University of Jordan, Amman, Jordan.

- $\quad$ Akbas, F.; W. J. Armstrong and R. Petkova. (2011). Idiosyncratic Volatility of Liquidity and Expected Stock Returns. Working Paper, Purdue University.

- Akram, N. (2014). "The Effect of Liquidity on Stock Returns: Evidence from Pakistan", IOSR Journal of Business and Management, 16 (2), 66-69.

- Amihud, Y. (2002). "Illiquidity and Stock Returns: Cross-Section and Time-Series Effects", Journal of Financial Markets, 5 (1), 31-56

- $\quad$ Amihud, Y. and H. Mendelson. (1986). "Liquidity and Stock Returns", Financial Analysts Journal, 42 (3), 43-48.

- Batten, A. and V. Vo. (2014). "Liquidity and Return Relationship in an Emerging Market", Emerging Markets Finance and Trade, 50 (1), 5-21.

- $\quad$ Bekaert, G.; C. R. Harvey and C. Lundblad. (2007). "Liquidity and expected returns: Lessons from emerging markets", Review of Financial Studies, 20(6), 1783-1831.

- $\quad$ Bond, A. and Q. Chang. (2013). "Liquidity Risk and Stock Returns: A Return Decomposition Approach", In: Midwest Finance Association 2013 Annual Meeting Paper. Available at SSRN: http://ssrn.com/abstract=2148729.

- Cao, C. and L. Petrasek. (2014). "Liquidity Risk in Stock Returns: An Event-Study Perspective", Journal of banking and finance, 45 (c), 72-83.

- Chacko, G. (2005). Liquidity Risk in the Corporate Bond Markets. Harvard University and State Street Global Markets, Working Paper, January.

- Chen, M. and H. Lee. (2013). Default Risk, Liquidity Risk, and Equity Returns: Evidence from the Taiwan Market. Emerging Markets Finance and Trade, 49 (1), 101-129.

- Chikore, R.; W. Gachira, W. D. Nkomo and W. Chiwanza. (2014). Stock Liquidity and Returns: Evidence from the Zimbabwe Stock Exchange. Interdisciplinary Journal of Contemporary Research in Business, 6, 20-35.

- Chordia, T.; A. Sarkar and A. Subramaniam. (2005). The Joint Dynamics of Liquidity, Returns, and Volatility across Small and Large Firms, Working Paper, UCLA.

- Dalgaard, R. (2009). "Liquidity and Stock Returns: Evidence from Denmark", $\boldsymbol{M}$. Sc. thesis, Copenhagen Business School.

- Diether, B.; J. Malloy and A. Scherbina. (2002). "Differences of Opinion and the Cross Section of Stock Returns", The Journal of Finance, 57 (5), 2113-2141

- Erten, I. and N. Okay. (2012). Deciphering Liquidity Risk on the Istanbul Stock Exchange. MPRA Paper, University Library of Munich, Germany. http://EconPapers.repec. org/RePEc:pra:mprapa:56148.

- Fama, E. F. and K. R. French. (1992). The Cross-Section of Expected Stock Returns. The Journal of Finance, 47(2), 427-465

- Fama, E. F. and K. R. French. (1993). Common Risk Factors in the Returns on Stocks and Bonds. Journal of Financial Economics. 33: 3-65.

- Fu, F.; W. Kang, W. and Y. Shao. (2012). Liquidity Variation and the Cross-Section of Stock Returns. Five Star Forum in Finance, China. Available at: http://ink.library.smu. edu.sg/lkcsb_research/3267.

- Giouvris, E. (2003). Systematic Liquidity and Expected Returns: Evidence from the 
London Stock Exchange .Evangelos Giouvris, Dept. of Economics \& Finance. Available at SSRN: http://ssrn.com/abstract=406695.

- $\quad$ Hameed, A.; W. Kang and S. Viswanathan. (2010). Stock Market Declines and Liquidity. The Journal of Finance, 65 (1), 257-293.

- Jang, J.; J. Kang and C. Lee. (2012). "Liquidity Risk and Asset Returns in Korea", Asia-Pacific Journal of Financial Studies, 41(6), 704-738.

- Kaniel, R.; G. Saar and S. Titman. (2008). "Individual Investor Trading and Stock Returns", The Journal of Finance, 63 (1), 273-310.

- Li, B.; Q. Sun and C. Wang. (2014). "Liquidity, liquidity Risk and Stock Returns: Evidence from Japan” European Financial Management, 20 (1), 126-151.

- Liang, X. and K. Wei. (2012). "Liquidity Risk and Stock Returns around the World", Journal of Banking \& Finance, 36 (12), 3274-3288.

- $\quad$ Mazouz, K.; D. W. Alrabadi and S. Yin. (2009). Systematic Liquidity Risk and Stock Price Reaction to Shocks: Evidence from London Stock Exchange. Available at SSRN: http://ssrn.com/abstract=1407135.

- $\quad$ Morken, M. A. and M. Jerkø. (2012). "Priced Liquidity Risk Factors at the Oslo Stock Exchange", Master's Thesis, Norwegian University of Science and Technology,

- Novák, J. (2014). Does Stock Liquidity Explain the Premium for Stock Price Momentum?", Finance A Uver: Czech Journal of Economics \& Finance, 64 (1), 79-95.

- $\quad$ Pastor, L. and F. Stambaugh. (2001). Liquidity Risk and Expected Stock Returns. National Bureau of Economic Research. Paper No. W8462, Available at SSRN: http://ssrn.com/ abstract $=282688$.

- $\quad$ Salehi, M.; G. Talebnia and B. Ghorbani. (2011). "A Study of the Relationship between Liquidity and Stock Returns", World Applied Sciences Journal of Companies Listed in Tehran Stock Exchange, 12, 1403-1408.

- $\quad$ Spiegel, M. I. and X. Wang. (2005). Cross-Sectional Variation in Stock Returns: Liquidity and Idiosyncratic Risk. http://ssrn.com/abstract=709781.

- Uddin, M. H. (2009). "Reexamination of Stock Liquidity Risk with a Relative Measure", Studies in Economics and Finance, 26(1), 24-35.

- Vovchak, V. (2013). Liquidity and Liquidity Risk in the Cross-Section of Stock Returns. January 8. Available at SSRN: http://dx.doi.org/10.2139/ssrn.2078295.

- Watanabe, A. and M. Watanabe. (2008). "Time-Varying Liquidity Risk and the Cross Section of Stock Returns”, Review of Financial Studies, 21 (6), 2449-2486.

- $\quad \mathrm{Xu}, \mathrm{B}$. and J. Watada. (2008). "Liquidity Impact on Sector Returns of Stock Market: Evidence of China", Asia Pacific Journal of Finance and Banking Research, 2 (2)

- Yuanhui, L. (2008). Empirical Research of Liquidity Risk Based on China's Stock Market. In: Risk Management \& Engineering Management. ICRMEM'08. International Conference on IEEE.387-392.

- Zhang, H. H. and J. P. Pereira. (2008). "Stock Returns and the Volatility of Liquidity", In: EFA 2005 Moscow Meetings. Available at SSRN: http://ssrn.com/abstract=556807. 